\title{
The Effect of Job Security on the Commitment of Teachers in Ghana: The Mediating Role of Career Satisfaction
}

\author{
HENRY AMEYAW DOMFEH ${ }^{1}$, WILLIAM D. HUNSAKER ${ }^{2 *}$ \\ School of Business Administration \\ Kyungpook National University \\ 80 Daehak-Ro, Buk-Gu, Daegu, 41566 \\ SOUTH KOREA
}

\begin{abstract}
This study sought to assess the effect of job security on the commitment of teachers in the Cape Coast Metropolis of Ghana. The study further assessed the mediating role of career satisfaction in the relationship between job security and organizational commitment. Using an explanatory survey design, 228 senior high school teachers were systematically selected and surveyed accordingly. The estimated target population was 530 teachers. An internal consistency of .807 was recorded for the instrument. Data processing and analysis were done using SPSS and SMART PLS to assess the effect of job security on the four dimensions of organizational commitment (affective, continuance, normative, and value commitment). The measurement model met all the quality criteria. It was found that job security had a positive influence on all four dimensions of organizational commitment as well as career satisfaction. Similarly, career satisfaction had a positive influence on all four dimensions of organizational commitment. Furthermore, career satisfaction mediated the relationships among job security and all dimensions of organizational commitment except value commitment. Thus, the findings suggest that Ghana Education Service should institute policies and measures that enable teachers to feel more secure in their job, and increase their opportunities for career development in Ghana's public senior high schools. Additionally, teachers should take advantage of human resource development policies initiated by their respective institutions to increase the level of their career satisfaction and consequently, their commitment to their respective schools.
\end{abstract}

Key-words: job security, organizational commitment, career satisfaction, teachers, education

Received: October 7, 2019. Revised: March 23, 2020. Accepted: April 6, 2020. Published: April 14, 2020.

\section{Introduction}

Education is an essential tool for fostering holistic national development. Countries worldwide are actively seeking means to promote quality education for their citizens [53]. Quality education is essential in every sphere of life as it enables individuals to acquire the skills, knowledge, and good behaviors required by society. Teachers are the key instrument in promoting quality education in Ghana. Therefore, it is necessary to implement measures that will effectively position teachers to deliver on their mandate [41]. In this study, teachers are classified as public sector employees, generally comprising those employed by the state.

The most important thing that people in developing nations care about is the security of their jobs [20]. However, the lack of job security still remains a problem in Ghana. A lack of job security is the non-quantifiable attribute that characterizes public sector employment, owing to factors such as perceived under-rewarding, outmoded working structures, and lack of in-service training for teachers $[9,53,40]$. Job security is a necessity for most employees, as its absence causes employees to experience sustained stress $[10,48]$. The psychological pain an individual undergoes as a result of losing a job is equal to the unpleasantness of unemployment itself [11]. Dachapalli and Parumasur [15] stressed that every employee's level of insecurity heightens when they observe a threat to their job. Afebia [1] opined that, in Ghana, male teachers in the public sector were more likely to quit the teaching profession than female teachers. However, is this situation the same for public teachers in the senior high schools of Cape Coast Metropolis in Ghana?

Career satisfaction continues to be a very dominant indicator of idiosyncratic career success and can be seen as a critical factor influencing career success in real labor market situations [24]. Most employees relate their career success with that of their coworkers, which influences their turnover intention and commitment levels. Thus, the career satisfaction of workers may rise or fall contingent 
upon the value they place on their coworkers' careers [16]. It has been established that workers with high levels of job security exhibit higher performance [34]. Thus, high performance and commitment have been proven to be functions of job security [20]. Many countries are still beyond the reach of these studies, although there have been advancements in cross-national studies and research $[10,30]$.

This research seeks to examine the effect of job security on the organizational commitment of public senior high school teachers in Cape Coast Metropolis, Ghana. It further seeks to assess the mediating effect of career satisfaction in the predictive relationships between job security and organizational commitment.

\section{Literature Review}

\subsection{Concept of Job Security}

Unemployment and job security remain issues of vital interest to many nations [46] and workers are very concerned about unemployment when they lose a job [6]. Every employee's desire is to have a secure job [13] and every employer's desire is to retain or find new employees [46]. Whenever there is a reduction in job openings, there is a relative upsurge in job loss [7]. Job security is the hope an employee has concerning the continuity and stability of their employment. It concerns the employees' emotions regarding the loss of a job or desired aspects of a job such as good working conditions, promotions, or desired long-term career prospects [2]. Herzberg [26] viewed job security as the extent of satisfaction a worker experiences in his/her employment. Recently, in most countries, job security has been falling at an increasing rate owing to technological advancements, demographic variations, and government strategies [46].

Many studies regarding employee motivation state that the best motivation for an employee is his/her salary. However, we can deduce that, without job security, an employee may not continue to receive pay in the long run. Clark [13] found that job security is the key attribute among seven important job attributes. This finding confirms that the real motivation an organization can provide its employees is job security. Job security is seen as the extrinsic part of commitment [35]. Thus, employees tend to show only partial commitment to an organization whenever their job security is at stake. Most workers perceive job security as an indispensable right [33] and the most influential means of motivating them [8]. Additionally, job security allows employees to be certain about their future, reduces labor agitations, increases productivity, helps to protect the social balance and values [22], and reduces employees' intention to quit [6]. This indicates that the concept of job security is pivotal in today's competitive business environment [46].

\subsection{Concept of Organizational Commitment}

Organizational commitment is a key element for the success of an organization. Commitment gives companies a competitive edge over their rivals and helps to increase productivity, effectiveness, and lower employee turnover [51]. Therefore, the concept of commitment must be given sufficient attention [47]. Meyer and Allen [37] defined organizational commitment as "a mental and emotional state that embodies a worker's association with the company, and this has consequences for their decision to remain as members in such organizations." Meyer and Herscovitch [38] elaborated that commitment is "a course of actions of importance that binds a person to one or more specific targets." In the case of teachers, such commitment is seen the emotional attachment that emerges as they share their values with colleagues [2].

Organizational commitment comprises four dimensions: affective commitment, continuance commitment, normative commitment, and value commitment [3]. Cohen [14] defined affective commitment as the 'employees' passionate attachment, empathy with, and participation in an organization." Thus, when an employee has a strong level of affective commitment, it means that he/she has a mind-set of believing in and identifying with their institutions. Therefore, such individuals remain with the company because they want to. Akpan [2] believes that affective commitment is more intrinsic than extrinsic in nature and further stressed that affective commitment among teachers can be improved by (a) ensuring good human interactions (b) including staff in decision-making processes, and (c) dispositional features like locus of control.

Piyasena and Kottawatta [42] defined continuance commitment as "the apparent cost related to leaving a particular company." This includes the potential cost of exiting a company, the wastage of time, energy spent gaining nonprofitable abilities and skills, the loss of certain fringe benefits, and also the cost associated with leaving certain valuable relationships in the company [43]. Additionally, continuance commitment depends on two basic factors: the number of investments a person makes in his/her 
current company and the apparent absence of choices [12].

According to Allen and Meyer [3], normative commitment "is the workers' feeling of duty to stay with the company." Employees that demonstrate strong normative commitment internalize a set of norms concerning appropriate conduct [32]. Implicitly, workers experience normative commitment because they think the organization has invested in them (for instance, through training and development) and hence, need to repay the organization.

Ritzer and Trice [44] defined value commitment as a state of mind that occurs due to the existence of subjectively distinct rewards related to a specific position that the individual desires or finds himself in. Researchers seeking to measure an individual's level of value commitment often ask the question: "what attracts an individual to a position?" In light of these arguments, research findings suggest that value commitment is the readiness of an individual to exert effort in his/her job [36].

\subsection{Concept of Career Satisfaction}

Career satisfaction refers to "a person's perception of their current career achievements and view of future progress" [31]. Careers are influenced by education, tenure, level of commitment, skills, abilities, and promotions [52]. Therefore, career satisfaction is based on the success one attains intrinsically and extrinsically with regards to expert connections and mentoring [18]. Moreover, when workers foresee a compatibility between their wishes and ambitions, they tend to have strong organizational commitment, career satisfaction, and little intention to exit the company. However, employees tend to exit the organization when they feel that their wishes and ambitions are incompatible with their work environment [28].

\subsection{Mediation Effects of Career Satisfaction}

The conceptual framework in this paper is based on psychological contract theory and social exchange theory, which assumes that a social exchange was the outcome of the necessity to recognize the subjective and indeterminate relations between workers and managers [4, 27]. A psychological contract is referred to as the unwritten hopes between employees and employers [5]. Accordingly, a psychological contract is the belief a person has in terms of reciprocal obligations [45]. From the workers' viewpoint, a psychological contract must comprise [5]: (a) How workers are treated with regards to consistency, impartiality, and fairness

(b) Employment security

(c) Demonstration of know-how

(d) Career expectations and opportunities to further improve skills

(e) Participation and influence

(f) Trust in leaders to execute their promises

From the employers' viewpoint, a psychological contract encompasses compliance, trustworthiness, effort, and capability [5]. When employees perceive that their employer is unwilling to offer permanent jobs even though it is possible, they hold back engagement and loyalty. In other words, they show a negative attitude via less dedication to the organization [17]. Psychological contracts are the foundation of employee commitment [39]. This theory states that if an employer engages its employees and provides them with job security, the employees will also offer some form of organizational commitment.

Iverson [29] found a positive relationship between job security and organizational commitment. However, no study has considered career satisfaction as a mediating variable in the relationship between job security and organizational commitment. Considering the importance that employees place on job security in their work environment, which involves providing an employment guarantee for the work they do, we suggest that when employees have positive feelings about their psychological contract in terms of job security, it increases their career satisfaction. Subsequently, employees will have a positive feeling toward reciprocal obligations in the form of organizational commitment.

Moreover, based on the social relationship that exists between employers and employees, employees who experience job security in their work are likely to demonstrate organizational commitment because they experience positive feelings that their career satisfaction is being improved due to job security. Based on these arguments, we expect that career satisfaction is a mechanism that explains how job security elicits employees' commitment in the organizations.

\subsection{Conceptual Framework}

Based on the logic underlying the psychological contract theory and based on the trends in empirical reviews related to the variables considered in this research, this study proposes that job security positively affects organizational commitment. Additionally, career satisfaction may play a 
mediating role in the relationship between job security and organizational commitment.

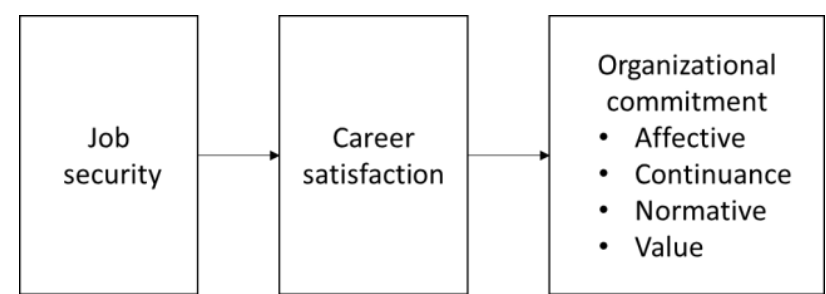

Fig.1. Conceptual framework of the model

\subsection{Hypotheses}

The following hypotheses were tested using appropriate statistical techniques based on the literature reviewed and the underlying notions of this study.

H1: Job security positively influences all organizational commitment dimensions (i.e., affective, continuance, normative, and value commitment).

H2: Job security positively influences career satisfaction.

H3: Career satisfaction positively influences organizational commitment.

H4: Career satisfaction positively mediates the relationship between job security and the four dimensions of organizational commitment.

\section{Methodology}

The study employed an explanatory survey design to measure the extent and nature of the cause-andeffect relationships. Explanatory studies are characterized by research hypotheses that specify the nature and direction of the relationships between or among the variables being studied [49]. This approach is deductive in nature, in that inferences from testing statistical hypotheses lead to general inferences about a population's characteristics. In this study, the population comprises public senior high school teachers in the Cape Coast Metropolis of Ghana. This sample excludes teachers employed in the private schools. The target population was 530 teachers. The study systematically selected 228 teachers to participate in this study.

Primary data was collected by administering structured questionnaires. The study employed a 7point Likert scale, ranging from strongly disagree to strongly agree, for all the variables used in the study.

The job security scale was adapted from Goretzki's [21] scale. This construct had nine selfassessment items regarding job security. The reliability of the job security scale was 0.773 .
The organizational commitment construct was adapted from Meyer and Allen's [37] scale, which comprised the four dimensions of commitment: affective (3 items), continuance ( 8 items), normative (3 items), and value (2 items) commitment. A reliability value of 0.794 was recorded for the composite value of organizational commitment.

The career satisfaction construct, adapted from Spurk, Abele, and Volmer's work [50], comprised five items. A reliability value of 0.893 was recorded for career satisfaction.

Data processing and analysis were conducted using SPSS and SMART PLS, based upon the reflective model specification within the structural model. The assessment of the reflective outer model involves examining the reliability of the individual items (indicator reliability) as well as the latent variables, and multiple aspects of validity, including the constructs, convergence, and discriminant validity [23].

\section{Analysis}

\subsection{Demographic Information}

Males represented $65.4 \%$ of the sample and $55.3 \%$ of the participants were married. All the participants had graduated from university while $26.8 \%$ had attended graduate school. Most participants $(64.9 \%)$ had worked as a teacher for at least five years.

\subsection{Reliability and Validity}

The correlations among variables in the conceptual model were all positive and significant $(p<.01)$ and ranged between .296 and .567, supporting the hypothesized relationships.

Table 1 shows that the reliability of the study's measures were all above .70. Additionally, the composite reliability (CR), which is considered a preferable alternative to the Cronbach's alpha, for testing convergent validity in reflective models, was above the .70 threshold for each measure, while the average variance extracted (AVE) coefficients were all above the .50 threshold, suggesting adequate convergent validity. Discriminant validity was measured using the Heterotrait-Monotrait Ratio (HTMT). The HTMT coefficient of all measures was below the .90 threshold, indicating the measures had discriminant validity $[19,25]$. 
Table 1. Construct Reliability and Validity

\begin{tabular}{l|l|l|l}
\hline & Alpha & CR & AVE \\
\hline Job security & .773 & .868 & .689 \\
\hline $\begin{array}{l}\text { Career } \\
\text { satisfaction }\end{array}$ & .893 & .921 & .700 \\
\hline $\begin{array}{l}\text { Affective } \\
\text { commitment }\end{array}$ & .844 & .906 & .763 \\
\hline $\begin{array}{l}\text { Continuance } \\
\text { commitment }\end{array}$ & .819 & .891 & .733 \\
\hline $\begin{array}{l}\text { Normative } \\
\text { commitment }\end{array}$ & .705 & .835 & .629 \\
\hline $\begin{array}{l}\text { Value } \\
\text { commitment }\end{array}$ & .809 & .912 & .838 \\
\hline
\end{tabular}

\subsection{Hypotheses Analysis}

SMART PLS was used to analyze the hypothesized path relationships in this paper. This application was chosen as it is recognized as a tool for estimating complex models in predictive studies [23]. It also helps to avoid the problem of a small sample size as it efficiently handles complex models that have many variables [25]. Furthermore, the approach enables researchers to use cause-effect relationship models to predict a specific construct.

As depicted in Figure 2, all of the predicted paths from job security to the organizational commitment dimensions with career satisfaction as a mediator were positive and significant, except for the paths to value commitment, which were all not significant. These results support the hypothesized relationships, except for value commitment.

The explained variance $\left(R^{2}\right)$ of job security and career satisfaction on organizational commitment dimensions is shown in Figure 2. Notably, the $R^{2}$ of the career satisfaction and organizational commitment dimensions revealed that job security accounted for $12.8 \%$ of the explained variance in career satisfaction among teachers and jointly with career satisfaction accounted for $21.5 \%, 19.2 \%$, $19.4 \%$, and $7.7 \%$ of the explained variance in affective, continuance, normative, and value commitment, respectively. These results support H1, $\mathrm{H} 2$, and $\mathrm{H} 3$.

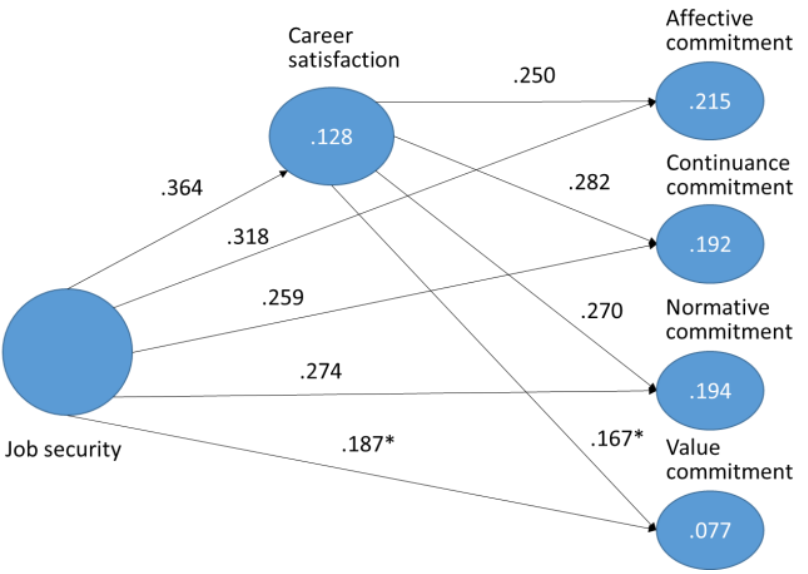

Fig. 2. Simplified results of the structural model. * not significant

H4 proposed that career satisfaction would mediate the effects of job security on the organizational commitment dimensions. Using SMART PLS, the indirect effects of job security on the commitment dimensions, mediated by career satisfaction, were calculated. The results show that job security had a positive and significant indirect effect on all dimensions, except value commitment, ranging from .109 to .132. In comparison, the direct effects of job security on all commitment dimensions, except value commitment, were significant, ranging from .311 to .380 . Thus, the results support H4, except for the proposed effects on value commitment.

\section{Discussion and Implications}

This study has several theoretical implications. The hypotheses tested provide support to the claims made in respect to the conceptualized model of this study. The tested hypotheses had their roots in psychological contract theory. Therefore, these findings contribute to the claims propounded by psychological contract theory, which states that workers expect some benefits from their employers in exchange for their efforts (in the form of service) apart from the terms regulating formally-signed employment contracts. Fulfilling these expectations could lead to positive working outcomes such as increased employee commitment. Thus, the capacity of the predictors, i.e., job security and career satisfaction, to generate positive variance in organizational commitment shows that employers need to be concerned with providing an enabling environment via human resource practices and policies that improve job security and career satisfaction among workers.

This study also has practical implications. Teachers should take advantage of the human 
resource development policies implemented by their respective institutions to increase their level of career satisfaction and hence their level of commitment toward their respective schools. Teachers must take personal responsibility for ensuring their job security by following all policy directions related to their advancement in the education sector as they are required to constantly upgrade themselves to be retained in a professional teaching career in the public education service sector in Ghana.

Furthermore, this study has several policy implications. The Ghana Education Service must institute policies and measures that offer teachers the opportunity to be more secure in their jobs, and must advance their career development options in the public senior high schools in Ghana at large. Policies for periodic research among teachers in public senior high schools is also being advocated for. These programs can be sponsored by the Ministry of Finance in conjunction with the Ministry of Education through the Ghana Education Trust Fund (GETFund). These surveys could be utilized to uncover the challenges, potential, and prospects in public education in Ghana to provide timely, accurate and reliable insights for managerial use and decision-making purposes.

\section{Limitations and Suggestions for Further Studies}

This study was conducted only in public senior high schools in Cape Coast Metropolis and thus the findings cannot be easily generalized to all schools in Ghana or other cultural contexts. Moreover, since the study employed a structured instrument for primary data collection, it was impossible to capture the individual opinions of the respondents for analysis and thus detailed findings cannot be assured.

Future studies should be conducted across different public senior high schools across various regions in Ghana and other cultural contexts. The scope of these studies should include both private and public schools as well as junior and senior high schools to increase the sample size. Some relevant studies in other contexts can be found in [54] and [55].

\section{Conclusion}

This study determined that the job security of public high school teachers in Ghana influences multiple dimensions of organizational commitment, as intervened by career satisfaction. The findings suggest that Ghana Education Service should institute policies and measures that enable teachers to feel more secure in their job, and increase their opportunities for career development.

\section{References:}

[1] Afebia, C. A. (2016). Assessment of turnover intentions and employee commitment among teachers of the Ghana education service in the Bolgatanga municipality (Doctoral dissertation, University of Ghana). Retrieved from http://ugspace.ug.edu.gh/handle/123456789/ 21333.

[2] Akpan, C. P. (2013). Job security and job satisfaction as determinants of organizational commitment among university teachers in cross river state, Nigeria. British Journal of Education, Vol. 1, No. 2, pp. 82-93.

[3] Allen, N. J., \& Meyer, J. P. (1990). Organizational socialization tactics: A longitudinal analysis of links to newcomers' commitment and role orientation. Academy of Management Journal, Vol. 33, No. 4, pp. 847-858.

[4] Argyris, C. (1960). Understanding Organizational Behavior. Homewood, IL: Dorsey Press.

[5] Armstrong, M. (2010). Armstrong's handbook of reward management practice: Improving performance through reward. Kogan Page Publishers.

[6] Artz, B., \& Kaya, I. (2014). Job insecurity and job satisfaction in the United States: the case of public sector union workers. Industrial Relations Journal, Vol. 45, No. 2, pp. 103-120.

[7] Artz, B., \& Kaya, I. (2014). The impact of job security on job satisfaction in economic contractions versus expansions. Applied Economics, Vol. 46, No. 24, pp. 2873-2890.

[8] Bakan, İ., \& Büyükbeşe, T. (2004). Yaratıcılık ve yaratıcılık yönetimi. Çăgdaş yönetim yaklaşımları, pp. 1-33.

[9] Berisha, D. (2017). Public Sector Wages: The Implications for the Private Sector.

[10] Bullock, J. B., Hansen, J. R., \& Houston, D. J. (2018). Sector differences in employee's perceived importance of income and job security: Can these be found across the contexts of countries, cultures, and occupations? International Public 
Management Journal, Vol. 21, No. 2, pp. 243-271.

[11] Burchell, B. (2011). A temporal comparison of the effects of unemployment and job insecurity on wellbeing. Sociological Research Online, Vol. 16, No. 1, pp. 1-13.

[12] Chen, Z. X., \& Francesco, A. M. (2003). The relationship between the three components of commitment and employee performance in China. Journal of vocational behavior, Vol. 62, No. 3, pp. 490-510.

[13] Clark, A. E. (2001). What really matters in a job? Hedonic measurement using quit data. Labour Economics, 8(2), 223-242.

[14] Cohen, A. (2003). Multiple commitments in the workplace: An integrative approach. Psychology Press.

[15] Dachapalli, L. A. P., \& Parumasur, S. B. (2012). Employee susceptibility to experiencing job insecurity. South African Journal of Economic and Management Sciences, Vol. 15, No. 1, pp. 16-30.

[16] Eddleston, K. A. (2009). The effects of social comparisons on managerial career satisfaction and turnover intentions. Career Development International, Vol. 14, No. 1, pp. 87-110.

[17] Furaker, B., \& Berglund, T. (2014). Job insecurity and organizational commitment. RIO: Revista internacional de organizaciones, No. 13, pp. 163-186.

[18] Ganiron Jr, T. U. (2013). Social capital and career success of civil engineers towards designing career paths. Procedia-social and Behavioral Sciences, Vol. 102, pp. 611-621.

[19] Garson, G. D. (2016). Partial least squares: Regression and structural equation models. Asheboro, NC: Statistical Associates Publishers.

[20] Gholamreza, J., Mokhles, A., \& Bahrami, H. (2011). The impact of job security on employee's commitment and job satisfaction in Qom municipalities. African Journal of Business Management, Vol. 5, No. 16, pp. 6853-6858.

[21] Goretzki, M. (2016). Determinants of perceived job security (Master's thesis). Retrieved from http://essay.utwente.n1/70997/1/Goretzki_ MA_BMS.pdf

[22] Guzel, A. (2001). İş Guvencesine İliş̧kin Temel İlke ve Eğilimler Işı̆̆ında Yasa
Tasarısının Değerlendirilmesi. İş Guvencesi Yasa Tasarısının Değerlendirme Semineri, İstanbul: İstanbul Barosu Yayınlart. pp. 19-49.

[23] Hair Jr, J. F., Hult, G. T. M., Ringle, C., \& Sarstedt, M. (2016). A primer on partial least squares structural equation modeling (PLS-SEM). Sage Publications.

[24] Hall, D. T., \& Chandler, D. E. (2005). Psychological success: When the career is a calling. Journal of Organizational Behavior, Vol. 26, No. 2, pp. 155-176.

[25] Henseler, J., Ringle, C. M., \& Sarstedt, M. (2012). A new criterion for assessing discriminant validity in variance-based structural equation modeling. Journal of the Academy of Marketing Science, Vol. 43, No. 1, pp. 115-135.

[26] Herzberg, F. (1968). One more time. How do you motivate employees, pp. 53-62.

[27] Homans, G. C. (1958). Social behavior as exchange. American Journal of Sociology, Vol. 63, No. 6, pp. 597-606.

[28] Igbaria, M., Greenhaus, J. H., \& Parasuraman, S. (1991). Career orientations of MIS employees: an empirical analysis. MIS Quarterly, pp. 151169.

[29] Iverson, R. D., \& Roy, P. (1994). A causal model of behavioral commitment: Evidence from a study of Australian bluecollar employees. Journal of Management, Vol. 20, No. 1, pp. 15-41.

[30] Jaskyte, K. (2016). Work values of public, nonprofit, and business employees: A cross-cultural evidence. International Journal of Public Administration, Vol. 39, No. 3, pp. 184-193.

[31] Judge, T. A., Cable, D. M., Boudreau, J. W., \& Bretz Jr, R. D. (1995). An empirical investigation of the predictors of executive career success. Personnel Psychology, Vol. 48, No. 3, pp. 485-519.

[32] Kerlinger, F. N., \& Lee, H. B. (2000). Foundations of behavioral research. Harcourt College Publishers.

[33] Koc, M. (2005). Tum Yönleriyle İş Güvencesi, Ankara. Yaklaşım Yayıncılık, pp. 20-23.

[34] Kraimer, M. L., Wayne, S. J., Liden, R. C., \& Sparrowe, R. T. (2005). The role of job security in understanding the relationship between employees' perceptions of temporary workers and employees' 
performance. Journal of Applied Psychology, Vol. 90, No. 2, pp. 389.

[35] Lambert, S. J. (1991). The combined effects of job and family characteristics on the job satisfaction, job involvement, and intrinsic motivation of men and women workers. Journal of Organizational Behavior, Vol. 12, No. 4, pp. 341-363.

[36] Mayer, R. C., \& Schoorman, F. D. (1998). Differentiating antecedents of organizational commitment: A test of March and Simon's model. Journal of Organizational Behavior, Vol. 19, No. 1, pp. 15-28.

[37] Meyer, J. P., \& Allen, N. J. (1991). A three-component conceptualization of organizational commitment. Human Resource Management Review, Vol. 1, No. 1, pp. 61-89.

[38] Meyer, J. P., \& Herscovitch, L. (2001). Commitment in the workplace: Toward a general model. Human Resource Management Review, Vol. 11, No. 3, pp. 299-326.

[39] Mullins, L. J. (2010). Management and organisational behaviour (9th ed.). Essex: Pearson Education Limited.

[40] Munnell, A. H., \& Fraenkel, R. C. (2013). Public sector workers and job security. State and local pension plans issue in brief, pp. 31.

[41] Osei, G. M. (2006). Teachers in Ghana: Issues of training, remuneration and effectiveness. International Journal of Educational Development, Vol. 26, No. 1, pp. 38-51.

[42] Piyasena, K. G. C. C., \& Kottawatta, H. (2018). Does engagement of employees affect organizational commitment? Evidence from non-academics in Sri Lankan state universities. Human Resource Management Journal, Vol. 6, No. 2.

[43] Purcell, J., Kinnie, N., Hutchinson, S. Rayton, B., \& Swart, J. (2003). Understanding the people and performance link: unlocking the black box. London.

[44] Ritzer, G., \& Trice, H. M. (1969). An empirical study of Howard Becker's sidebet theory. Social Forces, pp. 475-478.

[45] Rousseau, D. M. (1990). The 'problem' of the psychological contract considered. Journal of Organizational Behavior, Vol. 19, No. S1, pp. 665-671.
[46] Senol, F (2011). The effect of job security on the perception of external motivational tools: A study in hotel businesses. Journal of Economic and Social Studies, Vol. 1, No. 2, pp. 33-60.

[47] Shahid, A., \& Azhar, S. M. (2013). Gaining employee commitment: Linking to organizational effectiveness. Journal of Management Research, Vol. 5, No, 1, pp. 250.

[48] Siegrist, J. (2012). Effort-reward imbalance at work: Theory, measurement and evidence. Department of Medical Sociology, University Düsseldorf, Düsseldorf.

[49] Spirtes, P., Glymour, C., \& Scheines, R. (2000). Causation, prediction, and search. Adaptive computation and machine learning series. The MIT Press, 49, 77-78.

[50] Spurk, D., Abele, A. E., \& Volmer, J. (2015). The career satisfaction scale in context: A test for measurement invariance across four occupational groups. Journal of Career Assessment, Vol. 23, No. 2, pp. 191-209.

[51] Vance, R. J. (2006). Employee engagement and commitment. SHRM Foundation.

[52] Yap, M., Holmes, M. R., Hannan, C. A., \& Cukier, W. (2010). The relationship between diversity training, organizational commitment, and career satisfaction. Journal of European Industrial Training, Vol. 34, No. 6, pp. 519-538.

[53] Yidana, M. B., \& Partey, A. (2018). Economics teachers' conceptions of classroom assessment: A study of senior high schools in the central and Ashanti regions of Ghana. International Journal for Innovation Education and Research, Vol 6, No. 10, pp. 153-174.

[54] Friehs, B. (2015). The "Missing Species" Female students in STEM-fields: A qualitative study on young Austrian female students in gender-typical disciplines and STEM-fields. WSEAS Transactions on Advances in Engineering Education, Vol 12, pp. 86-94.

[55] Chugh, R. (2018). Tacit knowledge transfer in Australian universities: Exploring the barriers and enablers. WSEAS Transactions on Advances in Engineering Education, Vol 15, pp. 7-15. 